Molekul, Vol. 9. No. 2. November, 2014: 144 - 154

\title{
KARAKTER BENTONIT TERPILAR LOGAM ALUMINIUM PADA VARIASI SUHU KALSINASI
}

\section{THE CHARACTER OF ALUMINIUM METAL PILLARED BENTONITE AT VARIOUS CALCINATION TEMPERATURES}

\author{
Toeti Koestiari \\ Jurusan Kimia FMIPA Universitas Negeri Surabaya \\ e-mail : toeti.kustiari@gmail.com
}

\begin{abstract}
ABSTRAK
Penelitian ini bertujuan untuk mempelajari karakter bentonit terpilar logam aluminium pada berbagai suhu kalsinasi. Instrumen yang digunakan untuk melihat karakter fisikokimia adalah Spektrofotometer IR, X-ray Diffraction dan Gas Sorption Analyzer. Hasil yang diperoleh menunjukkan adanya persamaan dan perbedaan karakter dari B-Al yang dikalsinasi pada suhu 300,400 , dan $500{ }^{\circ} \mathrm{C}$. Persamaan karakter ketiga B-Al terletak di daerah gugus fungsional pada bilangan gelombang $1636 \mathrm{~cm}^{-1}$ dan $3500-4000 \mathrm{~cm}^{-1}$, serta sesuai dengan hasil XRD untuk lapis $\mathrm{SiO}_{2}$ dan $\mathrm{Al}_{2} \mathrm{O}_{3}$ yang tidak mengalami perubahan pada harga $d$, maupun bentuk pori yang dihasilkan menggunakan GSA. Perbedaan suhu kalsinasi menyebabkan perbedaan bilangan gelombang di daerah sidik jari yaitu adanya pita tajam yang disebabkan oleh banyaknya ion $\mathrm{Al}^{3+}$ di antar lapis terutama pada suhu kalsinasi $500{ }^{\circ} \mathrm{C}$. Jumlah ion $\mathrm{Al}^{3+}$ karena masuknya pemilar menyebabkan perbedaan luas permukaan ditunjukkan juga oleh GSA dengan harga radius pori dan luas permukaan tertinggi terletak pada $\mathrm{B}-\mathrm{Al} / 400^{\circ} \mathrm{C}$. Dengan demikian bentonit terpilar $\mathrm{Al}$ pada suhu kalsinasi $400{ }^{\circ} \mathrm{C}$ merupakan hasil yang terbaik ditinjau dari karakter fisiko-kimia.
\end{abstract}

Kata kunci: karakter fisiko-kimia, pemilaran, suhu kalsinasi.

\begin{abstract}
The objective of this research was to study Aluminum metal pillared bentonite characters at various calcination temperatures. The instrument used to see the physico-chemical character are Spectrophotometer IR, X-ray Diffraction and Gas Sorption Analyzer. The results can be seen the similarities and differences character of the $\mathrm{B}-\mathrm{Al}$ that calcined at 300,400 , and $500^{\circ} \mathrm{C}$. The similarities of the three $\mathrm{B}-\mathrm{Al}$ character is indicated in the functional groups at wave number $1636 \mathrm{~cm}^{-1}$ and $3500-4000 \mathrm{~cm}^{-1}$, as well as in accordance with the XRD results for $\mathrm{SiO}_{2}$ and $\mathrm{Al}_{2} \mathrm{O}_{3}$ layers that do not change in the distance interlayer, and the pore shapes using GSA. Calcination temperature differences lead to differences in the wave number of fingerprints that is the sharp band due to the amount of $\mathrm{Al}^{3+}$ ions in the interlayer especially at calcination temperature of $500{ }^{\circ} \mathrm{C}$. The number of $\mathrm{Al}^{3+}$ ions that intercalate as pillared cause the difference surface area is shown by the GSA whose the highest value of the pore radius and surface area is the $\mathrm{B}-\mathrm{Al} / 400{ }^{\circ} \mathrm{C}$. This means that the effect of calcination temperature at $400{ }^{\circ} \mathrm{C} \mathrm{Al}$ pillared bentonite is stabilized as shown by the average pore size and the best results in terms of the physico-chemicalcharacter.
\end{abstract}

Keywords: calcination temperature, physico-chemical character, pillared. 


\section{PENDAHULUAN}

Pembuatan kristal yang menggunakan beberapa cara tergantung dari jenis produk yang diinginkan. Sebagai contoh adalah polikristalin yang diguna- kan sebagai adsorben dapat disintesis melalui teknik interkalasi, impregnasi/insersi dan pertukaran ion dengan metode suhu rendah. Pada metode suhu rendah (pada atau sedikit di atas suhu kamar) beberapa reaksi dapat dilaksanakan untuk memodifikasi struktur material. Reaksi jenis ini disebut interkalasi insersi yaitu suatu ion atau molekul ditambahkan pada suatu senyawa namun struktur dasar senyawa yang dimasuki tidak berubah. Penambahan ion dilakukan dengan menyisipkan ion-ion ke dalam struktur yang telah ada dan menyebabkan reduksi pada senyawa awal (host) bila yang disisipkan adalah kation atau oksidasi bila yang yang disisipkan adalah anion (Ismunandar, 2006). Salah satu contohnya adalah penelitian yang dilakukan oleh Fatimah dan Wijaya (2006) yang mengemukakan terjadinya penurunan kadar $\mathrm{Al}$ dan $\mathrm{Si}$ serta reduksi mineral pengotor yang ada dalam montmorillonit pada saat proses dekomposisi. Teknik interkalasi ini dilakukan pada bahan yang mempunyai struktur berlapis dimana ada ikatan kovalen yang kuat dalam lapisan dan ikatan van der Waals antar lapisan. Keberhasilan interkalasi akan menyebabkan struktur material bentonit akan terpilar dan bersifat rigid.

Beberapa variabel yang diperhatikan pada proses pilarisasi adalah waktu, suhu, $\mathrm{pH}$ dalam hal ini derajat hidrolisis $\mathrm{OH} / \mathrm{L}$ (logam), konsentrasi ion logam, waktu dan suhu pertumbuhan, serta tipe counter ion (ion pengimbang). Metode suhu rendah ini berguna untuk membuat bahan-bahan reaktif yang memiliki luas permukaan besar dan dipergunakan untuk adsorben.

Penelitian ini menggunakan pemilar $\mathrm{AlCl}_{3}$ dengan bahan bentonit. $\mathrm{AlCl}_{3}$ adalah senyawa monomer pada suhu $800{ }^{\circ} \mathrm{C}$, sedangkan pada suhu di bawah $400{ }^{\circ} \mathrm{C}$ baik solid maupun uapnya berbentuk dimer dengan rumus molekul $\mathrm{Al}_{2} \mathrm{Cl}_{6}$ dan merupakan molekul dengan kisi tetrahedral (Quagliano, 1964). Molekul ini menunjukkan adanya perubahan ikatan dari ikatan ionik menjadi ikatan kovalen (West, 1988). $\mathrm{AlCl}_{3}$ digunakan sebagai bahan pemilar karena mudah dihidrolisis menjadi polimer $\mathrm{Al}$ (kation berukuran besar) yang disebut dengan "ion keggin $=\mathrm{Al}_{13}$ atau $\left[\begin{array}{lll}\mathrm{Al}_{13} \mathrm{O}_{4} & (\mathrm{OH})_{28}\end{array}\right]^{3+}$ (Smart and Moore, 2005). Bila basa $\mathrm{NaOH}$ yang digunakan untuk menghidrolisis larutan $\mathrm{AlCl}_{3}$ maka akan terbentuk kompleks $\left[\mathrm{Al}\left(\mathrm{H}_{2} \mathrm{O}\right)_{6}\right]^{3+}$ pada $\mathrm{pH}$ di bawah 3 . Tetapi bila $\mathrm{pH}$ dinaikkan, ligan $\mathrm{H}_{2} \mathrm{O}$ terdeprotonasi sehingga terbentuk $\left[\mathrm{Al}(\mathrm{OH})_{\mathrm{x}}\left(\mathrm{H}_{2} \mathrm{O}\right)_{6-\mathrm{x}}\right]^{(3-\mathrm{x})+.} \quad$ Spesies mononuklir dengan $\mathrm{x}=4$ hanya stabil dalam larutan sangat encer; sedangkan pada konsentrasi tinggi spesies polinuklir akan terbentuk melalui reaksi kondensasi dengan membentuk ikatan Al- O- Al (Schubert and Hüsing, 2000).

Perubahan Bentonit-terpilar pada berbagai suhu dapat diketahui dari jenis gugus fungsional bentonit, basal spacing, diameter pori, volume pori, luas permukaan bentonit. Penentuan gugus fungsi dilakukan menggunakan Spektrofotometer Infra Merah. Basal spacing dapat diketahui menggunakan alat X-Ray Diffraction (XRD), luas permukaan dan volume pori dapat ditentukan melalui metode adsorpsi gas $\mathrm{N}_{2}$ dengan menggunakan Gas Sorption Analyser. 


\section{METODE PENELITIAN}

\section{Alat dan Bahan}

Karakterisasi bentonit terpilar aluminium menggunakan X-Ray Diffraction JEOL JDX - 3530 , Spektrometer IR Buck Scientific - 500 dan AAS Perkin Elmer AA-100, Gas Sorption Analyser Quantachrome NovaWin2.

Bahan-bahan yang dipergunakan dalam penelitian ini semuanya dalam kemurnian pro analisis yaitu bentonit dan $\mathrm{AlCl}_{3}$. dari Sigma; $\mathrm{NaOH}$ dan $\mathrm{AgNO}_{3}$ dari E. Merck. Air dalam penelitian ini adalah Aquademineralisata

\section{Pembuatan bentonit-terpilar}

Pembuatan larutan pemilar dilakukan dengan mencampurkan $\mathrm{AlCl}_{3}$ 0,4 $\mathrm{M}$ dan larutan $\mathrm{NaOH} \quad 0,4 \quad \mathrm{M}$ dengan perbandingan $[\mathrm{OH}] / \mathrm{L}[\operatorname{Logam}]=2$ atau pH 4,18 yang diadopsi dari Tomul dan Balci (2007). Pada gelas kimia yang lain dimasukkan bentonit ke dalam aquademineralisata $(1 \mathrm{~g} / 50 \mathrm{~mL})$ dan diaduk selama dua jam. Suspensi didiamkan 2 hari, kemudian ditambah larutan pemilar dengan perbandingan $1 \mathrm{~g} /$ $25 \mathrm{~mL}$. Campuran diaduk selama 4 jam dan didiamkan selama 24 jam. Endapan disaring dan dicuci hingga bebas $\mathrm{Cl}^{-}$. Serbuk dikalsinasi pada suhu 300, 400, dan $500{ }^{\circ} \mathrm{C}$ selama 3 jam.

\section{Karakterisasi bentonit terpilar Aluminium}

Endapan bebas $\mathrm{Cl}^{-}$yaitu bentonit terpilar Aluminium (B-Al) selanjutnya dikenai perlakuan variasi suhu kalsinasi untuk mencari suhu optimal dengan waktu kalsinasi 3 jam. Perlakuan tersebut adalah dengan memanaskan B-Al pada suhu 300, 400 dan $500{ }^{\circ} \mathrm{C}$. Hasil pemanasan selanjutnya dikarakterisasi dengan Spektrofotometer Infra Merah untuk menentukan gugus fungsional utama dan XRD untuk menentukan basal spacing $\left(d_{001}\right)$ dan $2 \theta$, sedangkan untuk mengukur luas permukaan, volume pori, dan jari-jari pori menggunakan GSA.

\section{HASIL DAN PEMBAHASAN}

Spektra Infra merah untuk masing-masing Bentonit terpilar/Al setelah kalsinasi selama 3 jam pada suhu 300, 400, dan $500{ }^{\circ} \mathrm{C}$ ditunjukkan pada Gambar 1. Bilangan gelombang yang terbaca dari spektra pada Gambar 1 ditabulasi pada Tabel 1.

Tabel 1. Analisis spektra Infra merah Bentonit-Aluminium (B-Al) pada suhu kalsinasi $300,400,500{ }^{\circ} \mathrm{C}$ dengan lama pemanasan 3 jam

\begin{tabular}{|c|c|c|c|}
\hline \multirow{2}{*}{$\begin{array}{l}\text { Bilangan Gelombang } \\
\text { Teoritis }\left(\mathrm{cm}^{-1}\right)\end{array}$} & \multicolumn{3}{|c|}{ Bilangan Gelombang $\left(\mathrm{cm}^{-1}\right)$} \\
\hline & $\mathrm{B}-\mathrm{Al} / \mathbf{3 0 0}{ }^{\circ} \mathrm{C}$ & $\mathrm{B}-\mathrm{Al} / 400^{\circ} \mathrm{C}$ & $\mathrm{B}-\mathrm{Al} / \mathbf{5 0 0}{ }^{\circ} \mathrm{C}$ \\
\hline Deformasi $\mathrm{SiO}_{2}(792-795)$ & 792,4 & 794,3 & 796,2 \\
\hline $\begin{array}{c}\text { Vibrasi } \mathrm{OH} \text {, deformasi OH-kation } \\
\text { (847-950) }\end{array}$ & 919,2 & 918,5 & 923,9 \\
\hline $\begin{array}{l}\text { Vibrasi O-Al-OH dari oktahedral, ulur Si-O, } \\
\text { ulur Si-O-Si antisimetris (1000-1200) }\end{array}$ & 1051,1 & 1082,1 & 1059 \\
\hline Deformasi H-O-H (1635) & 1636,4 & 1636,4 & 1636,4 \\
\hline $\begin{array}{l}\text { Vibrasi OH air teradsorpsi, vibrasi O-Al-OH } \\
\text { dalam sesquioksida }(3400-3600)\end{array}$ & 3440,6 & 3457,4 & 3444,8 \\
\hline Ulur OH oktahedron silikat (3600-3800) & 3627,1 & 3627,2 & 3637,2 \\
\hline
\end{tabular}

Keterangan : bilangan gelombang teoritis dirangkum dari Grim (1968), Tan (1996), Katti dan Katti and Katti (2003), Tolstoy et al., (2003). 

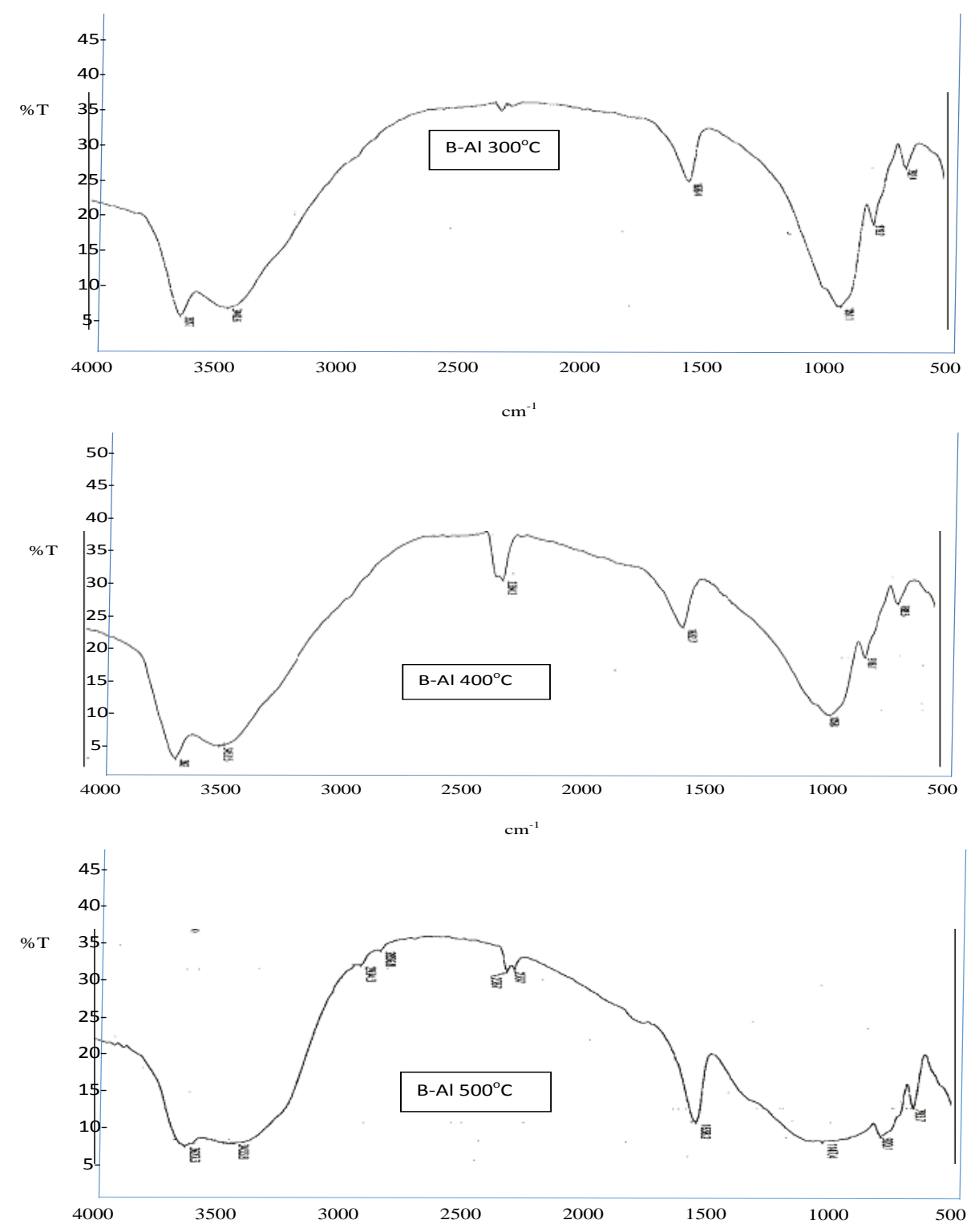

Gambar 1: Spektra IR untuk Bentonit-Al (B-Al) hasil kalsinasi 300, 400, $500{ }^{\circ} \mathrm{C}$.

Pada B/Al terdapat dua bagian gugus fungsional_yaitu gugus fungsional yang berhubungan dengan $\mathrm{H}-\mathrm{O}-\mathrm{H}$ dan daerah sidik jari yang berhubungan dengan lapisan tetrahedral/oktahedral (Tan, 1982). Persamaan B-Al/300 ${ }^{\circ} \mathrm{C}$ dan B$\mathrm{Al} / 400{ }^{\circ} \mathrm{C}$ terletak pada bilangan gelombang $3600-3800 \mathrm{~cm}^{-1}$ yang ditunjukkan oleh harga yang tidak berbeda secara signifikan, tetapi harga tersebut berbeda dengan $\mathrm{B}-\mathrm{Al} / 500{ }^{\circ} \mathrm{C}$. Menurut Tolstoy, et al., (2003) harga bilangan gelombang ini merupakan daerah $\mathrm{OH}$ yang terikat pada $\mathrm{Al}^{+3}$ atau adanya $\mathrm{OH}$ yang terikat diantara tetrahedral dan oktahedral. Frekuensi vibrasi yang tidak sama menunjukkan perbedaan kekuatan ikatan antara molekul, sehingga harga pada kalsinasi $500{ }^{\circ} \mathrm{C}$ lebih tinggi dibanding dua $\mathrm{B}-\mathrm{Al}$ yang lain.

Pada bilangan gelombang 3600 $3400 \mathrm{~cm}^{-1}$, bilangan gelombang B$\mathrm{Al} / 300{ }^{\circ} \mathrm{C}<\mathrm{B}-\mathrm{Al} / 500{ }^{\circ} \mathrm{C}<\mathrm{B}-\mathrm{Al} / 400{ }^{\circ} \mathrm{C}$. Hal ini bukan berarti bahwa air yang dikandung oleh $\mathrm{B}-\mathrm{Al} / 400{ }^{\circ} \mathrm{C}$ paling banyak tetapi juga adanya ikatan $\mathrm{OH}$ paling kuat yang terjadi karena adanya 
vibrasi O-Al-OH, dan pada $\mathrm{B}-\mathrm{Al} / 500{ }^{\circ} \mathrm{C}$ pemilar dimungkinkan tidak mengandung air karena kalsinasi.

Pada bilangan gelombang 1635 $\mathrm{cm}^{-1}$, ketiga $\mathrm{B}-\mathrm{Al}$ menunjukkan terjadinya vibrasi tekuk $\mathrm{H}-\mathrm{O}-\mathrm{H}$ yang sama. Dengan demikian dapat dikatakan bahwa ketiga B-Al mempunyai kestabilan jumlah air yang teradsorpsi setelah kalsinasi. Vibrasi pada bilangan gelombang ini menunjukkan kekuatan ikat dalam molekul dan massa tiap unsur dalam kisi kristal (Clark, 1999). Vibrasi pada bilangan gelombang $1200-1000$ $\mathrm{cm}^{-1}$ menunjukkan frekuensi vibrasi pada sampel B-Al/300 ${ }^{\circ} \mathrm{C}<\mathrm{B}-\mathrm{Al} / 500{ }^{\circ} \mathrm{C}<\mathrm{B}-$ $\mathrm{Al} / 400 \quad{ }^{\circ} \mathrm{C}$. Perbedaan tersebut menunjukkan adanya perubahan panjang ikatan O-Al-OH yang disebabkan substitusi gugus $\mathrm{Al}$ pada $\mathrm{Si}$ tetrahedral (Burch, 1988).

Antara bilangan gelombang 950 - $847 \mathrm{~cm}^{-1}$, data menunjukkan bahwa B$\mathrm{Al} / 400{ }^{\circ} \mathrm{C}<\mathrm{B}-\mathrm{Al} / 300{ }^{\circ} \mathrm{C}<\mathrm{B}-\mathrm{Al} / 500{ }^{\circ} \mathrm{C}$. Bilangan gelombang $\mathrm{B}-\mathrm{Al} / 400{ }^{\circ} \mathrm{C}$ paling rendah dibanding $\mathrm{B}-\mathrm{Al} / 500{ }^{\circ} \mathrm{C}$ karena pada kalsinasi terjadi pemakaian bersama $\mathrm{OH}$ dari $\mathrm{Al}$ oktahedral dengan $\mathrm{Si}$ tetrahedral. Menurut Tomul and Balci (2007), deformasi OH-kation ini menyebabkan adanya tempat (site) aktif asam Bronsted/Lewis dan dalam hal ini $\mathrm{B}-\mathrm{Al} / 400{ }^{\circ} \mathrm{C}$ lebih kuat dibanding B$\mathrm{Al} / 500{ }^{\circ} \mathrm{C}$.

Di daerah sidik jari yaitu bilangan gelombang $792-795 \mathrm{~cm}^{-1}$ data menunjukkan bahwa $\mathrm{B}-\mathrm{Al} / 300{ }^{\circ} \mathrm{C}<$ $\mathrm{B}-\mathrm{A} 1 / 400{ }^{\circ} \mathrm{C}<\mathrm{B}-\mathrm{Al} / 500{ }^{\circ} \mathrm{C}$. Vibrasi deformasi Si-O terbesar terletak pada B$\mathrm{Al} / 500 \quad{ }^{\circ} \mathrm{C}$ diperkirakan karena masuknya kation pemilar, sedangkan pada $\mathrm{B}-\mathrm{Al} / 300{ }^{\circ} \mathrm{C}$ dapat dikatakan belum terjadi pemilaran yang sempurna. Dengan demikian dapat dikatakan bahwa ketiga B-Al mempunyai persamaan dan perbedaan di daerah sidik jari dan pada daerah gugus fungsional. Persamaan dan perbedaan di daerah sidik jari dapat digunakan untuk mengetahui struktur bentonit yang berhubungan dengan lapis tetrahedral $\mathrm{SiO}_{2}$ dan lapis oktahedral $\mathrm{Al}_{2} \mathrm{O}_{3}$. Pada gugus fungsional persamaan dan perbedaan menunjukkan hubungan $\mathrm{H}-\mathrm{O}-\mathrm{H}$ sedangkan perubahan bilangan gelombang pada daerah sidik jari disebabkan terutama perubahan pada gugus fungsional $\mathrm{O}-\mathrm{Al}-\mathrm{OH}$. Perubahan ini terjadi karena pada pembentukan pemilar menggunakan konsentrasi $\mathrm{AlCl}_{3}$ $0,4 \mathrm{M}$ dan basa $\mathrm{NaOH} 0,4 \mathrm{M}$, sehingga terjadi reaksi kondensasi dengan membentuk ikatan Al-O-Al. Terbentuknya ikatan ini sesuai dengan Schubert and Hüsing (2000) yang menyatakan bahwa pada $\mathrm{pH}$ di bawah 3 akan terbentuk kation kompleks logam $\left[\mathrm{Al}\left(\mathrm{H}_{2} \mathrm{O}\right)_{6}\right]^{3+}$, sedangkan pada $\mathrm{pH}$ di atas 3 ligan air yang dikandung oleh bentonit akan terdeprotonisasi (Tan, 1982). Dengan demikian komposisi pemilar juga berpengaruh terhadap hasil vibrasi seperti yang ditunjukkan pada penelitian Okoye dan Cobi (2011) yang menggunakan senyawa $\mathrm{Al}(\mathrm{NO})_{3} .9 \mathrm{H}_{2} \mathrm{O}$, dimana intensitas $\mathrm{Si}-\mathrm{O}$ dan $\mathrm{Al}-\mathrm{O}$ sedikit turun pada pemilran.

Berdasarkan data infra merah dapat diketahui bahwa persamaan dari ketiga B-Al terletak pada daerah gugus fungsional bilangan gelombang $1636 \mathrm{~cm}^{-}$ ${ }^{1}$ yaitu terjadinya deformasi $\mathrm{H}-\mathrm{O}-\mathrm{H}$ dan bilangan gelombang $3500-4000 \mathrm{~cm}^{-1}$. Hal ini berarti bahwa adanya kestabilan jumlah air yang terikat setelah kalsinasi dan menunjukkan kekuatan ikat dalam molekul dan massa tiap unsur dalam kisi kristal yang sama.

Adanya perbedaan terletak pada bilangan gelombang di daerah sidik jari yaitu pada bilangan gelombang 1200$500 \mathrm{~cm}^{-1}$. Data infra merah menunjukkan $\mathrm{B}-\mathrm{Al} / 400{ }^{\circ} \mathrm{C}$ mempunyai pita tajam pada $1082,1 \mathrm{~cm}^{-1}$ yang berarti banyak ion $\mathrm{Al}^{+3}$ di oktahedral (Stuart, 2004). Pada bilangan gelombang didekat $3600 \mathrm{~cm}^{-}$ ${ }^{1}$ pita melebar berharga $3637,2 \mathrm{~cm}^{-1}$ 
untuk B-Al/500 ${ }^{\circ} \mathrm{C}$ menunjukkan bahwa pada suhu ini $3 \mathrm{OH}$ pada permukaan oktahedral membentuk ikatan $\mathrm{H}$ dengan $\mathrm{O}$ dari sisi tetrahedral lapisan berikutnya.

Hubungan antara suhu dan jarak antar bidang serta persamaan dan perbedaan struktur juga ditunjukkan oleh data difraktogram B-Al yang diperoleh dengan menggunakan $X$-ray Diffraction seperti yang terlihat pada Gambar 2. Difraktogram yang diperoleh terdiri dari montmorillonit, quartz dan muscovite. Difraktogram dari ketiga B-Al dari suhu yang berbeda ini dibandingkan dengan difraktogram dari bentonit host.

Struktur $\mathrm{SiO}_{2}$ dan struktur $\mathrm{Al}_{2} \mathrm{O}_{3}$ untuk B-S host tidak mengalami perubahan yang berarti dibandingkan dengan B-Al yang dikalsinasi pada 300, 400, dan $500{ }^{\circ} \mathrm{C}$. Data selengkapnya ditabulasikan di Tabel 2.

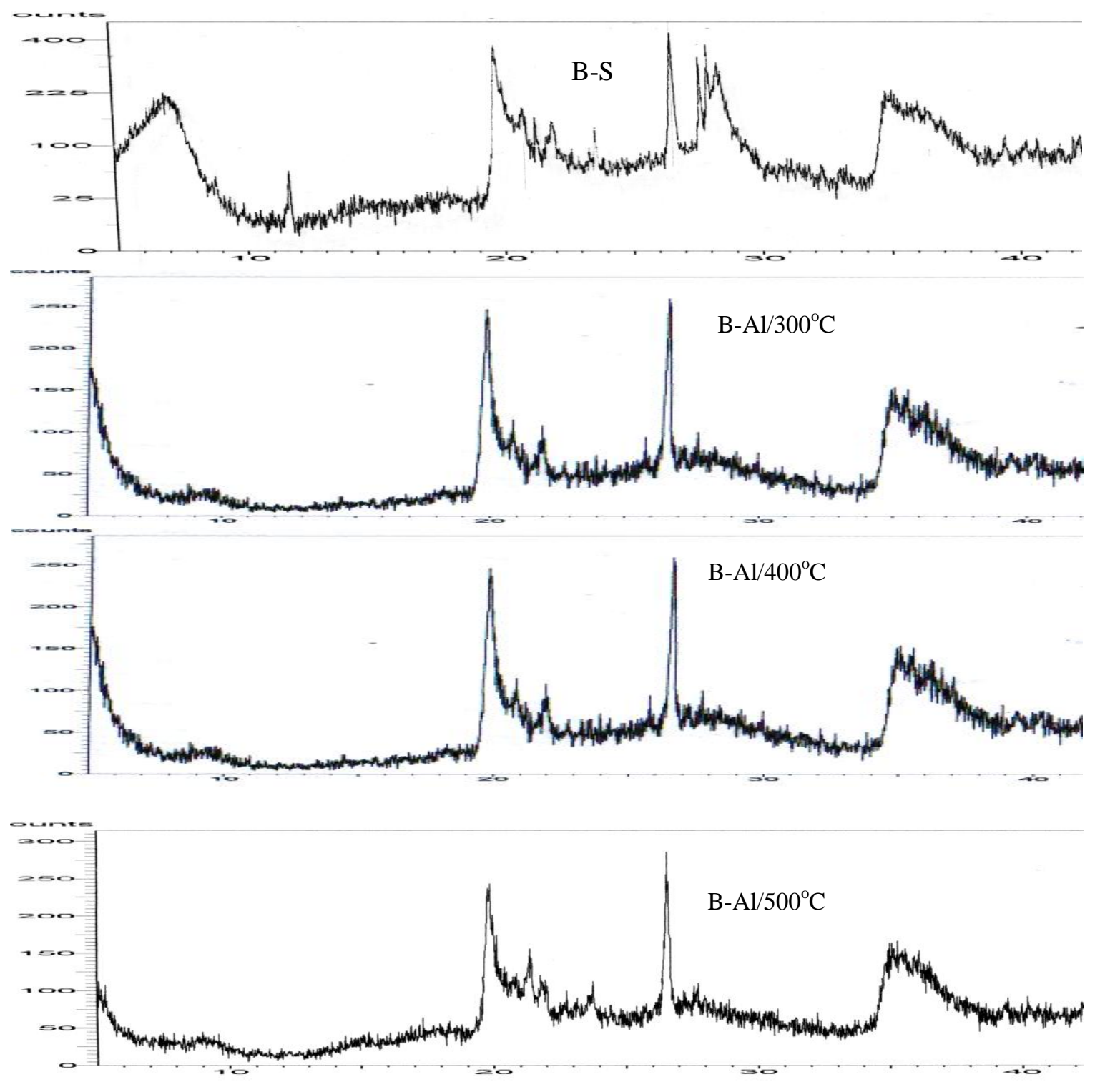

Gambar 2. Difraktogram XRD dari Bentonit host (B-S), Bentonit-Al (B-Al) hasil kalsinasi 300, 400, dan $500{ }^{\circ} \mathrm{C}$. 
Tabel 2. Harga $d_{001}$ dan $2 \Theta$ untuk Bentonit - Aluminium (B-Al) teraktivasi pada berbagai suhu dibandingkan Bentonit host (B-S).

\begin{tabular}{cccccccc}
\hline & \multicolumn{2}{c}{ Montmorillonit } & \multicolumn{3}{c}{$\mathbf{S i O}_{\mathbf{2}}$} & \multicolumn{2}{c}{$\mathbf{A l}_{\mathbf{2}} \mathbf{O}_{3}$} \\
& $\boldsymbol{d} \AA$ & $\mathbf{2 \theta}^{\mathbf{0}}$ & $\boldsymbol{d} \mathbf{\AA}$ & $\mathbf{2 \theta}^{\mathbf{0}}$ & $\boldsymbol{d} \AA$ & $\mathbf{2 \theta}^{\mathbf{o}}$ \\
\hline $\mathrm{B}-\mathrm{S}$ & 12,267 & 7,1015 & 4,2669 & 20,8600 & 2,5615 & 35,1520 \\
& 0 & & 3,3482 & 26,6400 & & \\
$\mathrm{~B}-\mathrm{Al} /$ & 9,5999 & 9,2045 & 4,4862 & 19,7733 & 2,5638 & 34,9683 \\
$300^{\circ} \mathrm{C}$ & & & 3,3518 & 26,5719 & & \\
$\mathrm{~B}-\mathrm{Al} /$ & 9,3047 & 9,4972 & 4,4764 & 19,8172 & 2,5635 & 34,9726 \\
$400^{\circ} \mathrm{C}$ & & & 3,3400 & 26,6350 & & \\
$\mathrm{~B}-\mathrm{Al} /$ & 16,841 & 5,2429 & 4,4716 & 19,8388 & 2,5667 & 34,9277 \\
$500^{\circ} \mathrm{C}$ & 6 & & 3,3475 & 26,6063 & & \\
\hline
\end{tabular}

Harga $\mathrm{d}_{001}$ Montmorillonit adalah $12,2670 \AA$ Á; pada $2 \theta: 7,1015^{\circ}$. Harga ini berubah untuk B-Al yang dikalsinasi pada suhu 300,400 , atau $500{ }^{\circ} \mathrm{C}$. Jarak antar bidang $\mathrm{B}-\mathrm{Al} / 300{ }^{\circ} \mathrm{C}$ dan $\mathrm{B}-\mathrm{Al} / 400$ ${ }^{\circ} \mathrm{C}$ dapat dikatakan berharga sama, tetapi berbeda dengan $\mathrm{B}-\mathrm{Al} / 500{ }^{\circ} \mathrm{C}$. Perbedaan jarak antar bidang menunjukkan adanya perubahan komponen yang terkandung di dalamnya dan dapat terjadi karena posisi atom dalam struktur yang berbeda. Meskipun demikian pada B-Al komponen penyusun bentonit yaitu $\mathrm{SiO}_{2}$ dan $\mathrm{Al}_{2} \mathrm{O}_{3}$ belum mengalami kerusakan atau dengan kata lain posisi atom tidak mengalami perubahan dalam sel satuan. Berdasarkan harga tersebut dapat dianalisis bahwa diantara ketiga $\mathrm{B}-\mathrm{Al}$ jarak antar bidang yang dimiliki oleh B$\mathrm{Al} / 300{ }^{\circ} \mathrm{C}$ hampir sama dengan $\mathrm{B}$ $\mathrm{Al} / 400{ }^{\circ} \mathrm{C}$ karena adanya pemilar yang memperkuat struktur antar bidang. Harga jarak antar bidang pada $\mathrm{B}-\mathrm{Al} / 500{ }^{\circ} \mathrm{C}$ paling besar karena pada suhu ini terjadi deformasi montmorillonit, sehingga jarak antar bidang terdeteksi pada posisi difraksi $2 \theta=5,2429^{\circ}$. Posisi difraksi yang berlainan menandakan adanya pengaruh atom penyusun bentonit yang berlainan, dan hal tersebut mempengaruhi intensitas difraksi sinar X. Analisis ini sesuai dengan analisis yang dihasilkan oleh spektra infra merah yang menyatakan adanya ulur $\mathrm{O}-\mathrm{H}$ dari struktur silikat. Dengan demikian perbedaan jarak antar bidang disebabkan karena jumlah atom dan posisi atom dalam sel (West, 1988). Hal ini juga dikemukakan oleh Tomul dan Balci (2007) yang menyatakan bahwa jumlah spesi interkalat menyebabkan jarak antar pilar dan berpengaruh pada luas permukaan dan kekuatan struktur kristal. Struktur kristal ini berkaitan dengan jumlah elektron yang terkandung pada titik tertentu dan diketahui sebagai intensitas I (Ismunandar, 2006). Spesi interkalat yang menyebabkan jarak antar pilar juga dikemukakan oleh Taslimah dan Azmiawati (2008). Pada penelitiannya dinyatakan bahwa pada kalsinasi $300{ }^{\circ} \mathrm{C}$ terbentuk $\gamma$-alumina dan pada $500{ }^{\circ} \mathrm{C}$ terbentuk $\beta$-alumina, sedangkan pada $400{ }^{\circ} \mathrm{C}$ fasa transisi alumina masih belum stabil sehingga ruang antar lapis masih mengalami perubahan. Sebaliknya pada penelitian yang telah dilakukan, justru suhu $400{ }^{\circ} \mathrm{C}$ yang merupakan suhu optimum, karena tidak menggunakan molekul pengarah (template) seperti yang digunakan oleh Taslimah dan Azmiawati (2008). Sesuai dengan Tan (1982), maka $d_{001}$ untuk B$\mathrm{A} 1 / 500{ }^{0} \mathrm{C}$ merupakan bentonit kering udara dan pada penelitian ini data menunjukkan adanya perubahan warna dari abu-abu menjadi kemerahan.

Karakterisasi juga dilakukan menggunakan GSA dengan tujuan untuk 
mengetahui pengaruh suhu terhadap sistem pori bentonit, luas permukaan, dan jari-jari pori. Hasil yang didapatkan ditunjukkan pada Gambar 3 dan datanya ditabulasi pada Tabel 3. Pori- pori yang ada pada ketiga Bentonit-Al (B-Al) dapat diketahui tipenya berdasarkan adsorpsi-desorpsi BET menurut klasifikasi de Boer (Oscik, 1982).

Tabel 3. Karakter Bentonit-Al (B-Al) hasil kalsinasi pada suhu 300 , 400, dan $500{ }^{\circ} \mathrm{C}$ menggunakan GSA

\begin{tabular}{cccc}
\hline Karakter & B-Al/ 300 ${ }^{\mathbf{}} \mathbf{C}$ & B-Al $/ \mathbf{4 0 0}^{\mathbf{}} \mathbf{C}$ & B-Al $/ \mathbf{5 0 0}{ }^{\mathbf{O}} \mathbf{C}$ \\
\hline P/P $\mathrm{P}_{0} H L(\mathrm{~atm})$ & $0,4513-0,5007$ & $0,4494-0,5512$ & $0,4497-0,5541$ \\
Volume $H L(\mathrm{cc} / \mathrm{g})$ & $73,5639-89,9465$ & $82,3687-97,6947$ & $78,0538-91,8979$ \\
Luas permukaan $\left(\mathrm{m}^{2} / \mathrm{g}\right)$ & 193,316 & 217,021 & 208,807 \\
Kapasitas adsorpsi $(\mathrm{cc} / \mathrm{g})$ & 113,8618 & 112,3119 & 112,6130 \\
Volume Pori Total $(\mathrm{cc} / \mathrm{g})$ & $1,761 \times 10^{-1}$ & $1,737 \times 10^{-1}$ & $1,737 \times 10^{-1}$ \\
Rata-rataUkuran Pori $(\AA)$ & 18,2212 & 16,0110 & 16,6124 \\
\hline
\end{tabular}

Keterangan: HL: hysterisis loops, $\mathrm{P}_{0}$ : tekanan awal, B-A1/300 ${ }^{\circ} \mathrm{C}$ : Bentonit-Aluminium pada suhu kalsinasi $300{ }^{\circ} \mathrm{C}, \mathrm{B}-\mathrm{Al} / 400{ }^{\circ} \mathrm{C}$ : Bentonit-Aluminium pada suhu kalsinasi $400{ }^{\circ} \mathrm{C}$, dan $\mathrm{B}-\mathrm{A} 1 / 500{ }^{\circ} \mathrm{C}$ : Bentonit-Aluminium pada suhu kalsinasi $500{ }^{\circ} \mathrm{C}$.

Pada proses adsorpsi-desorpsi BET, ketiga B-Al menunjukkan karakteristik tipe pori khusus karena menghasilkan hysterisis loops pada tekanan relatif dengan volume tertentu seperti yang

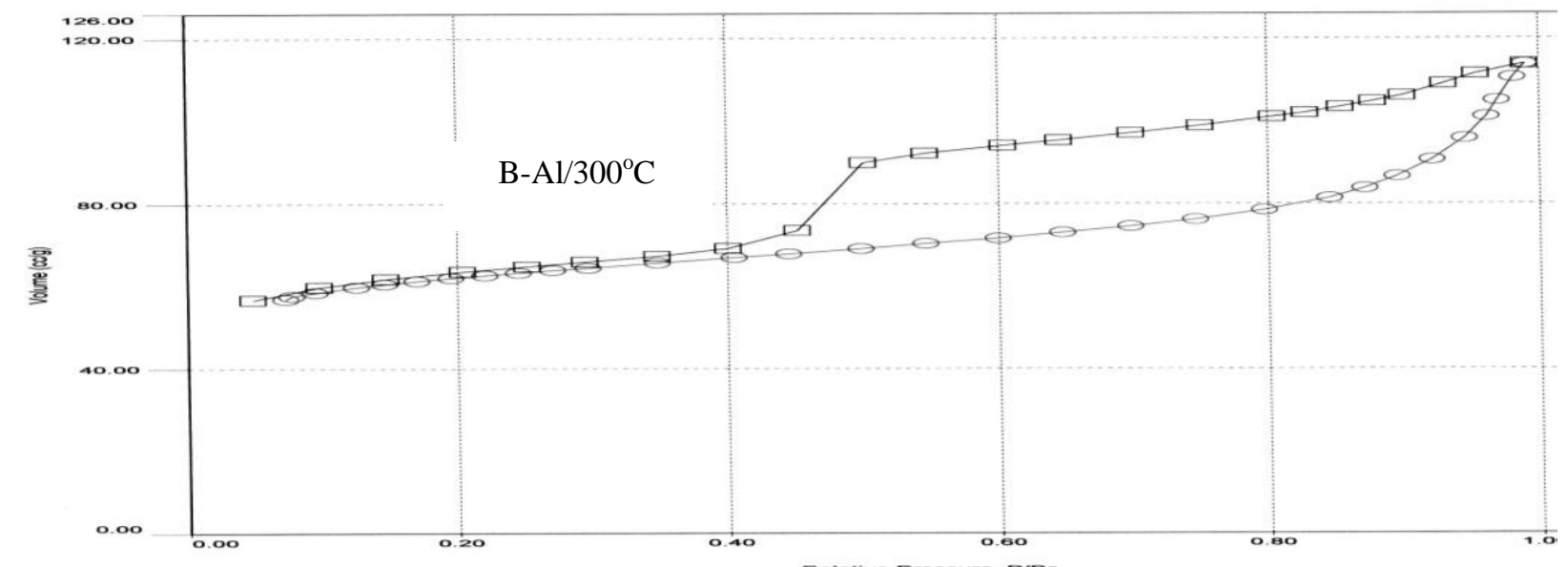

Gambar 3. Isoterm adsorpsi-desorpsi $\mathrm{N}_{2}$ untuk sampel Bentonit-Al (B-Al) setelah kalsinasi pada suhu 300,400 , dan $500{ }^{\circ} \mathrm{C}$. 

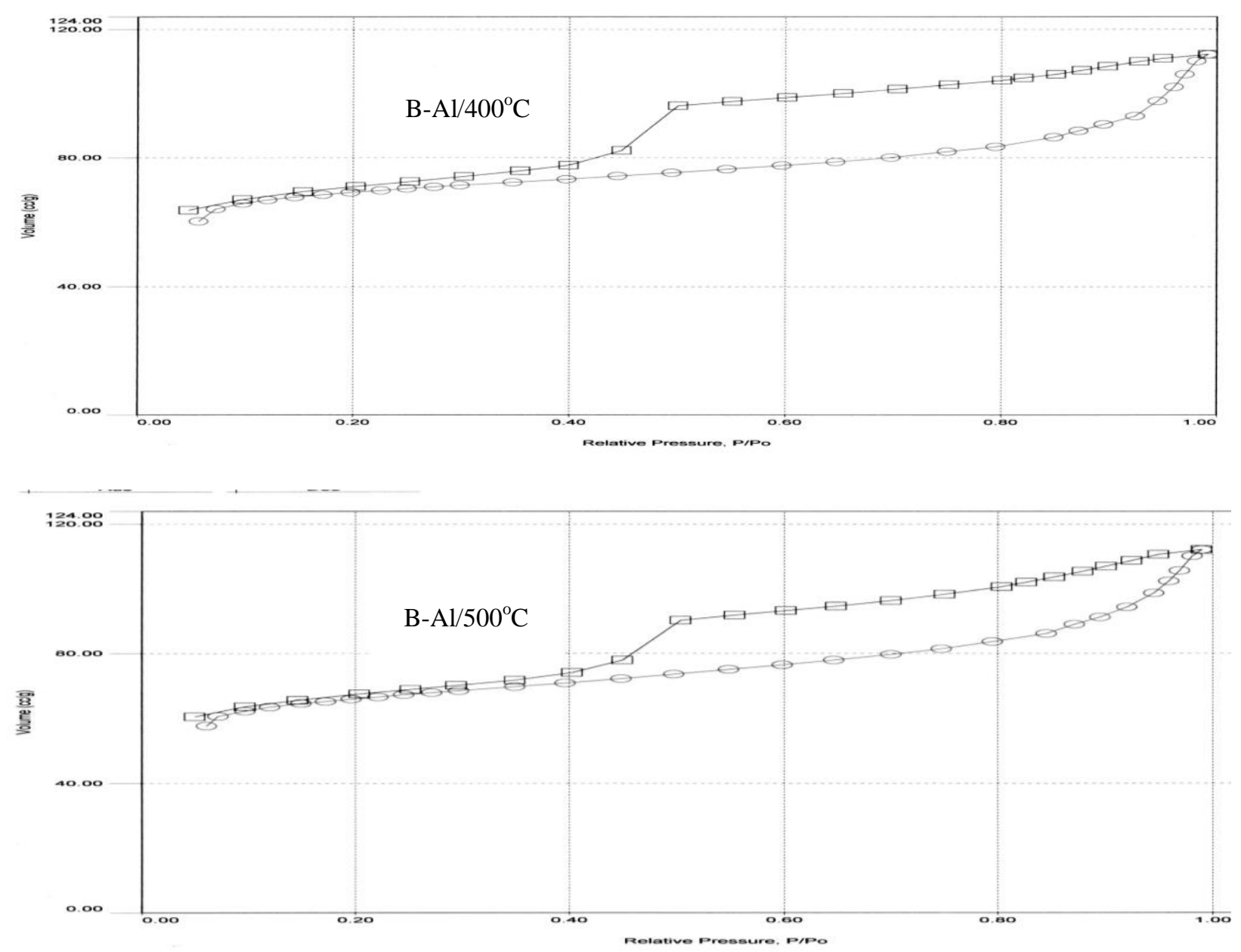

Gambar 3. (lanjutan) Isoterm adsorpsi-desorpsi $\mathrm{N}_{2}$ untuk sampel Bentonit-Al (B-Al) setelah kalsinasi pada suhu 300,400 , dan $500{ }^{\circ} \mathrm{C}$.

Keterangan: kurva dengan lambang bulatan = adsorpsi. kurva dengan lambang kotak $=$ desorpsi.

Berdasarkan proses adsorpsi desorpsi tersebut dapat dikemukakan bahwa ketiga B-Al mempunyai tipe pori golongan $\mathrm{E}$ dari klasifikasi de Boer (Oscik, 1982) yaitu pori yang mempunyai bentuk botol tinta (bottle ink). Diantara ketiga $\mathrm{B}-\mathrm{Al}, \mathrm{B}-\mathrm{Al} / 400{ }^{\circ} \mathrm{C}$ merupakan bentonit yang mempunyai kapasitas adsorpsi yang paling kecil dan tekanan relatif rendah meskipun kapasitas adsorpsinya maupun tekanannya hampir sama dengan B$\mathrm{Al} / 500{ }^{\circ} \mathrm{C}$. Melalui proses desorpsi dapat diketahui tekanan relatif B$\mathrm{Al} / 400{ }^{\circ} \mathrm{C}$ paling besar dengan kapasitas desorpsi tertinggi.
Menggunakan Tabel 3 juga dapat diketahui bahwa luas permukaan B$\mathrm{Al} / 400{ }^{\circ} \mathrm{C}$ mempunyai harga yang tertinggi $=217,021 \mathrm{~m}^{2} / \mathrm{g}$. Diantara ketiga $\mathrm{B}-\mathrm{Al}, \mathrm{B}-\mathrm{Al} / 400{ }^{\circ} \mathrm{C}$ mempunyai luas permukaandan radius pori terkecil, meskipun volume pori total lebih rendah dibandingkan $\mathrm{B}-\mathrm{Al} / 300 \quad{ }^{\circ} \mathrm{C}$. Melihat harga tersebut juga dapat dianalisis bahwa radius pori $\mathrm{B}-\mathrm{Al} / 400{ }^{\circ} \mathrm{C}$ lebih seragam dibanding $\mathrm{B}-\mathrm{Al}$ yang lain dengan ukuran pori rata-rata $=16,0100$ Á, meskipun ukuran untuk seluruh bentonit adalah mikropori.

$\mathrm{B}-\mathrm{Al} / 500{ }^{\circ} \mathrm{C}$ mempunyai luas permukaan yang lebih rendah dibanding $\mathrm{B}-\mathrm{Al} / 400{ }^{\circ} \mathrm{C}$, karena adanya pemilar $\mathrm{Al}$ 
yang terhidrasi. Pembentukan pemilar tidak hanya dipengaruhi oleh $\mathrm{pH}$ campuran, tetapi juga dipengaruhi oleh kalsinasi. Menurut Schubert and Hüsing (2000) lempung terpilar Al ditentukan oleh ion antar-lapis dengan larutan yang mengandung kation $\left[\mathrm{Al}_{13} \mathrm{O}_{4}(\mathrm{OH})_{24}\left(\mathrm{H}_{2} \mathrm{O}\right)_{12}\right]^{7+}$ atau disingkat ion ${ }_{13} \mathrm{Al}$ yang masuk (interkalasi) dalam bentonit. Setelah proses kalsinasi sekitar $500{ }^{\circ} \mathrm{C}$, ion ${ }_{13} \mathrm{Al}$ terhidrasi dan berubah menjadi partikel $\mathrm{Al}_{2} \mathrm{O}_{3}$ yang memilar lapisan tetrahedral-oktahedral aluminosilikat dari smektit sehingga terbentuk pori-pori. Dehidrasi dimulai pada suhu $200{ }^{\circ} \mathrm{C}$ dan bersamaan dengan itu daerah antar bidang mulai mengkerut, serta stabil pada suhu $500{ }^{\circ} \mathrm{C}$ (Smart, and Moore 2005). Pada penelitian Lubis (2007) dihasilkan luas permukaan 72,42 $\mathrm{m}^{2} / \mathrm{gr}$ dengan jari-jari pori rata-rata 1,08 nm. Pemilar yang digunakan adalah $\mathrm{AlCl}_{3}$ 0,1 $\mathrm{M}$ dan $\mathrm{NaOH}$ 0,5 $\mathrm{M}$ dengan perbandingan $\mathrm{OH} / \mathrm{L}=2$ dan hasilnya dikalsinasi pada suhu $500{ }^{\circ} \mathrm{C}$. Sementara itu penelitian yang dilakukan oleh Xuan Zhang dkk. (2012) menggunakan pemilar campuran $\mathrm{Fe}\left(\mathrm{NO}_{3}\right)_{3}$ dan $\mathrm{Al}\left(\mathrm{NO}_{3}\right)_{3}$ yang dihidrolisis dengan $\mathrm{Na}_{2} \mathrm{CO}_{3}$ sehingga diperoleh perbandingan $\mathrm{OH} /(\mathrm{Al}+\mathrm{Fe})=2$. Hasil yang diperoleh kemudian dikalsinasi pada suhu $350{ }^{\circ} \mathrm{C}$. Apabila dilakukan pencucian monmorillonit dengan $\mathrm{NaCl}$ sebelum proses pemilaran seperti yang dilakukan oleh El Miz dkk. (2014) dan kemudian setelah pemilaran dikalsinasi pada suhu $350{ }^{\circ} \mathrm{C}$, maka akan didapatkan luas permukaa total yang lebih besar dan volume pori total yang lebih kecil dibandingkan penelitian yang telah dilakukan.

\section{KESIMPULAN}

Kalsinasi pada suhu 300, 400, dan $500{ }^{\circ} \mathrm{C}$ dari B-Al menunjukkan persamaan dan perbedaan karakter fisiko-kimianya. Persamaan karakter ketiga B-Al terletak di daerah gugus fungsional bilangan gelombang $1636 \mathrm{~cm}^{-}$ ${ }^{1}$ yaitu terjadinya deformasi $\mathrm{H}-\mathrm{O}-\mathrm{H}$ dan pada $3500-4000 \mathrm{~cm}^{-1}$ yang berarti adanya kestabilan jumlah air yang terikat setelah kalsinasi dan menunjukkan kekuatan ikat dalam molekul dan massa tiap unsur dalam kisi kristal yang sama. Hal ini sesuai dengan hasil XRD untuk lapis $\mathrm{SiO}_{2}$ dan $\mathrm{Al}_{2} \mathrm{O}_{3}$ yang tidak mengalami perubahan pada harga $d$, maupun bentuk pori yang dihasilkan menggunakan GSA.

Perbedaan suhu kalsinasi menyebabkan perbedaan pada bilangan gelombang di daerah sidik jari yaitu adanya pita tajam yang disebabkan oleh banyaknya ion $\mathrm{Al}^{3+}$ di antar lapis. Kalsinasi B-Al pada suhu yang berlainan menyebabkan perbedaan $d_{001}$ terutama pada suhu kalsinasi $500{ }^{\circ} \mathrm{C}$. Jumlah ion $\mathrm{Al}^{3+}$ yang bertambah karena masuknya pemilar menyebabkan perbedaan luas permukaan ditunjukkan juga oleh GSA dengan harga radius pori dan luas permukaan tertinggi terletak pada B$\mathrm{Al} / 400{ }^{\circ} \mathrm{C}$. Hal ini berarti bahwa pada suhu kalsinasi $400{ }^{\circ} \mathrm{C}$ bentonit terpilar $\mathrm{Al}$ mulai stabil seperti yang ditunjukkan oleh rata-rata ukuran pori yang tidak berbeda jauh dengan kalsinasi pada suhu $500{ }^{\circ} \mathrm{C}$.

\section{DAFTAR PUSTAKA}

Burch, R. 1988. Pillared Clay-Catalysis to Day. Amsterdam: Elsevier Science Publisher.

Clark, R. N. 1999.Spectroscopy of Rocks and Minerals, and Principles of Spectroscopy. New York: John Wiley \& Sons, Inc. A. Rencz Editor.

El M, M. Salhi, S. Chraibi, I. El B, A. Laure F, M. Tahani, A. 2014. Characterization and Adsorption Study of Thymol on Pillared Bentonite. Open Journal of Physical Chemistry. 4 $(98-116)$. 
Fatimah, I. dan Wijaya, K. 2006. Pengaruh Metode Preparasi Terhadap Karakter Fisikokimia Montmorillonit Termodifikasi $\mathrm{ZrO}_{2}$. Akta Kimindo. Vol 1. No.2.

Grim, R.E. 1968. Clay Mineralogy. New York : Mc. Graw-Hill Book Company.

Ismunandar. 2006. Padatan Oksida Logam, Struktur, Sintesis, dan Sifat-sifatnya. Bandung: Penerbit ITB.

Katti, K. and Katti, D. 2003. Effect of Clay-Water Interactions on Swelling In Montmorillonit Clay .North Dakota State University: Fargo

Lubis, S. 2007. Preparasi Bentonit Terpilar Alumina dari Bentonit Alam dan Pemanfaatannya Sebagai Katalis pada Reaksi Dehidroksi Etanol, 1 Propanol Serta 2 Propanol. Jurnal Rekayasa Kimia dan Lingkungan. Vol 6. No. 2

Okoye, I.P. and Cobi. 2011. Synthesis and Characterization of $\mathrm{Al}$ Pillared Bentonite Clay Minerals. Research Journal of Applied Sciences. $6(7-12)$.

Ościk, J. 1982. Adsorption. Chichester, Toronto : John Wiley \& Sons.

Quagliano, J.V. 1964. Chemistry. New York: Englewood Cliffs-Prentice Hall, Inc.

Rouquerol, F.; Rouquerol, J.; Sing, K. 1999. Adsorption by Powders \& Porous Solids. New York : Academic Press

Schubert, U. and Hüsing, N. 2000. Synthesis of Inorganic Materials. Weinheim New York : Wiley-VCH.
Smart, L.E. and Moore, E.A. 2005. Solid State Chemistry. New York : Taylor \& Francis Group LLC

Stuart, B. 2004. Infra Red Spectroscopy: Fundamentals and Applications. John Wiley \& Sons.

Tan, K.H. 1982. Principles Of Soil Chemistry. New York : Marcel Dekker

Taslimah, R. K. dan Azmiawati, Choiril. 2008. Pilarisasi Lempung dengan $\mathrm{Al}_{2} \mathrm{O}_{3}$ untuk Agen Pemucat Minyak Sawit. Jurnal Kimia Sains dan Aplikasi. Vol.4. No. 3.

Tolstoy, V. P.; Chernystiova, I. V; Skryshevsky, V. A. 2003. Hand Book of Infra Red Spectra of Ultrathin Films. New Yersey: John Wiley \& Sons, Inc.

Tomul, F. and Balci, S. 2007. Synthesis and Characterization of Al-Pillared Inter - layered Bentonites. G. U. Journal of Science. 21 (1).

West, A.R. 1988. Basic Solid State Chemistry. New York, Toronto, Singapore: John Wiley \& Sons.

Xuang Zhang. Qian Wang. Honglei Jiang. 2012. Research on the Preparation of the Environmental Friendly Pillared Bentonite and Its Catalytic Properties. $\quad 2^{\text {nd }}$ International Conference on Electronic \& Mechanical Engineering and Information Technology. Atlantis Press. Paris. France. 